\title{
Restaurant Reviews in Brazil and the USA: A Feast of Cultural Differences and Their Impact on Translation'
}

\author{
Rozane Rodrigues Rebechi \\ rozane.rebechi@ufrgs.br \\ Universidade Federal do Rio Grande do Sul (UFRGS), Brazil
}

Rayane Ramos Nunes

nunes.rayaneramos@gmail.com

Universidade Federal do Rio Grande do Sul (UFRGS), Brazil

Laura Rodrigues Munhoz

lauramunhoz8@gmail.com

Universidade Federal do Rio Grande do Sul (UFRGS) , Brazil

\section{Nathália Oliva Marcon}

ntolivam@gmail.com

Universidade Federal do Rio Grande do Sul (UFRGS) , Brazil

\begin{abstract}
This article shares the findings from a study aimed to create a bilingual English-Portuguese glossary of terms and collocations characteristic of restaurant reviews, especially concerning the search for translation equivalents. Relying on the assumptions of corpus linguistics, we conducted both quantitative and qualitative analyses to investigate a comparable corpus of texts published in the United States and Brazil. The manual investigation of simple and compound keywords retrieved with Sketch Engine showed that the functional translation of texts pertaining to the genre restaurant review in that pair of languages goes far beyond terminological equivalence, since it should also consider the specificities of the genre in both languages and cultures. We observed that not only are American texts much longer than their Brazilian Portuguese counterparts, but the former are also significantly more technical than the latter. Moreover, restaurant reviews unveil a number of cultural differences when written in different languages for a distinct target audience. To produce texts that work properly for the target reader, the translator should be aware of the conventions of this domain in both languages and cultures before deciding what aspects should be maintained, adapted, or omitted. In addition, elements that do not recur in both lists
\end{abstract}

1 This article is an outcome of the project 'Culinária para Fins Acadêmicos: compilação de um corpus de textos culinários com foco na tradução’ [Culinary for Academic Purposes: the compilation of a corpus of culinary texts for translation] 
also reveal cultural differences between texts of a similar genre. We concluded that corpora may not only help translators to interpret source language texts, but also assist them in finding solutions for the translation process.

Keywords: Restaurant review; genre; functional translation; corpus linguistics; conventionality.

\section{Reseñas gastronómicas en Brasil y Estados Unidos: una variedad de diferencias culturales y su impacto en la traducción}

\section{Resumen}

Este artículo divulga los hallazgos de un estudio que se propuso construir un glosario bilingüe inglés-portugués de términos y expresiones características de las reseñas gastronómicas, en particular lo relativo a la búsqueda de equivalentes de traducción. Basados en los principios de la lingüística de corpus, se realizaron análisis cuantitativos y cualitativos para investigar un corpus comparable de textos publicados en Estados Unidos y Brasil. La investigación manual de palabras claves simples y compuestas recuperadas con Sketch Engine mostró que la traducción funcionalista de textos relativos al género reseña gastronómica en ese par de lenguas va más allá de la equivalencia terminológica, pues debería contemplar además las especificidades del género en ambos idiomas y culturas. Se observó que no solo los textos estadounidenses son mucho más extensos que los de sus contrapartes en portugués brasileño, sino que los primeros también son mucho más técnicos que los segundos. Más aún, las reseñas gastronómicas revelan varias diferencias culturales cuando se redactar en idiomas distintos para audiencias diferentes. Para producir textos que funcionen correctamente para el lector objetivo, el traductor debe estar al tanto de las convenciones de este campo en ambos idiomas y culturas, antes de decidir qué aspectos deben mantenerse, adaptarse u omitirse. Además, los elementos que no sean recurrentes en ambas listas también revelan diferencias culturales entre textos de un género similar. Concluimos que los corpus pueden no solo ayudar a los traductores a interpreter los textos en la lengua de partida, sino también apoyarlos en la búsqueda de soluciones para el proceso traductivo.

Palabras clave: reseñas gastronómicas; género; traducción funcional; lingüística de corpus; convencionalidad.

\section{Críticas gastronômicas no Brasil e nos Estados Unidos: um banquete de diferenças culturais e seu impacto na tradução}

\section{Resumo}

O objetivo deste artigo é compartilhar constatações resultantes de uma pesquisa que teve por finalidade a construção de um glossário bilíngue (português-inglês) de termos e colocações características de críticas gastronômicas, com atenção especial à busca de equivalentes tradutórios. Tendo como fundamentação os pressupostos da Linguística de Corpus, conduzimos análises quantitativas e qualitativas de um corpus comparável de textos publicados nos Estados Unidos e no Brasil. A investigação manual das palavras-chave simples e compostas, extraídas com a ferramenta Sketch Engine, evidenciou que a tradução funcional de textos pertencentes ao gênero crítica gastronômica nesse par de línguas vai muito além da equivalência terminológica, uma vez que as especificidades desse gênero nas diferentes línguas e culturas devem ser consideradas durante o processo tradutório. Os textos em inglês norte-americano não apenas são mais longos do que aqueles em português brasileiro, mas também apresentam um grau consideravelmente maior de tecnicismo, conforme evidenciado pelas palavras-chave. A fim de produzir textos funcionalmente adequados ao público-alvo, o tradutor deve estar ciente das convencionalidades da área em ambas as línguas/culturas para poder decidir quais aspectos devem ser mantidos, adaptados ou omitidos. Concluímos que o uso de corpora não apenas auxilia o tradutor a interpretar os textos na língua de partida, como também aponta soluções tradutórias 
para o texto de chegada. Ademais, elementos que não recorrem em ambas as línguas revelam diferenças culturais entre textos de gêneros similares que também devem ser observadas no processo tradutório.

Palavras-chave: crítica gastronômica; gênero textual; tradução funcional; linguística de corpus; convencionalidade.

\section{Critiques gastronomiques au Brésil et aux États-Unis : un festin de différences culturelles et leur impact sur la traduction}

L'objectif de cet article est de partager les résultats d'une recherche visant la production d'un glossaire bilingue (portugais-anglais) de termes et de scénarios caractéristiques de la critique gastronomique, avec une attention particulière à la recherche d'équivalents de traduction. Sur la base des hypothèses de la linguistique de corpus, nous avons effectué des analyses quantitatives et qualitatives d'un corpus comparable de textes publiés aux États-Unis et au Brésil. La recherche manuelle de mots-clés simples et composés, extraits à l'aide de l'outil Sketch Engine, a montré que la traduction fonctionnelle de textes appartenant au genre de la critique alimentaire dans cette paire de langues va bien au-delà de l'équivalence terminologique, parce que les spécificités de ce genre dans différentes langues et cultures doivent être prises en compte au cours du processus de traduction. Les textes en anglais nord-américain sont non seulement plus longs que ceux en portugais brésilien, mais ils présentent également un degré de technicité considérablement plus élevé, comme en témoignent les termes clés. Afin de produire des textes fonctionnellement adaptés au public cible, le traducteur doit connaître les conventions du domaine dans les deux langues et cultures pour décider des aspects à maintenir, à adapter ou à omettre. Nous concluons que l'utilisation de corpus n'aide pas seulement le traducteur à interpréter les textes en langue source, mais qu'elle indique également des solutions de traduction pour le texte cible. En outre, les éléments qui n'utilisent pas les deux langues révèlent des différences culturelles entre des textes de genres similaires qui doivent également être observées dans le processus de traduction.

Mots-clés : critique gastronomique ; genre textuel ; traduction fonctionnelle ; linguistique de corpus ; convention. 


\begin{abstract}
Anzitutto ci sembra indispensabile restituire alla storia della cucina una sua specifica dimensione.

La tentazione di sottoporla all'egemonia della letteratura, per secoli l'espressione più alta e autorevole del buon gusto, ha portato a esiti contraddittori: ritrovare, da un lato, nei consumi e negli stili conviviali, il riflesso di un ideale di civiltà;

ribadire, dall'altro, la subordinazione delle arti minori (materiali) alle arti maggiori (spirituali). ${ }^{2}$
\end{abstract}

(Capatti \& Montanari, 1999, p. 1)

\section{Introduction}

Food-related topics were for a long time neglected as subjects of academic research, as pointed out by Capatti and Montanari (1999) and Rebechi and Tagnin (2020), among others, and restaurant reviews are no exception. In her analysis of Brazilian restaurant reviews from the communication perspective, Amaral (2006) claims that, concerning cultural expressions, literature, music, cinema, and theater are recollected, whereas gastronomic journalism tends to be forgotten. Nevertheless, probably following the trend of television shows and movies in which gastronomy takes center stage, nowadays food evaluations are also becoming a trendy topic of research in the fields of sociology (Blank, 2007), discourse analysis (Waliszewska, 2018), cultural studies (Chik \& Vásquez, 2016), and business administration (Motoyama \& Usher, 2020), to cite but a few studies dedicated to the theme. Regarding translation studies, restaurant reviews are not a crowd favorite, at least when the pair of languages English-Portuguese is considered.

2 First of all, it seems indispensable to restore a specific dimension to the history of cooking. The temptation to subject it to the hegemony of literature, for centuries the highest and authoritative expression of good taste, has led to contradictory results: to find, on the one hand, in consumption and convivial style, the reflection of an ideal civilization; on the other hand, to reaffirm the subordination of the minor (material) arts to the major (spiritual) arts. (Our translation, as well as others in this article.)
Possibly as a consequence of this neglect there are scarce reference works in the area, and we believe that this type of material could help translators in this domain to deal with terminological and functional equivalence.

To contribute to bridge this gap, we created a bilingual English-Portuguese glossary of terms and collocations characteristic of restaurant reviews ${ }^{3}$. During this task, we realized that in this genre, the differences go far beyond linguistic equivalence when written in those languages and within those cultures. In addition to the difficulties inherent in translating any text genre, mainly the ones with a great amount of cultural elements - after all, as pointed out by Jakobson ([1959] 2012, p. 129), "[1]anguages differ essentially in what they must convey and not in what they may convey"-, Brazilian and American ${ }^{4}$ restaurant reviews uncovered what we call macro and micro textual differences that should be taken into account both in the translation and in the writing processes of this text genre, especially if the translator or writer is committed to producing a functional text (cf. Nord, 2006, 2012) which will sound fluent to the target reader, that is, which is conventional.

When translating texts pertaining to specialized fields, the translator is usually concerned about the appropriate terminology to render the concepts expressed in the source texts. Translation professionals are obviously aware that decontextualized terms are not enough to help them produce a conventional text in the target language and they look for materials that provide them with collocates and phraseologies, as well as contextualized examples. However, we believe that many other genre-specific linguistic dicionariogastronomico/

4 The corpus comprises reviews published in the United States only. The generalization to American aims to ease readability. 
and cultural characteristics should inform a functional translation. Food-related elements are an important expression of a culture, and as such, they demand a number of decisions when translated from one culture to another (Newmark, 1988); and the translators and writers should make those decisions without ever losing sight of the purposes of the task.

The aim of this study is twofold. Firstly, we intend to raise the translators' and writers' awareness of the differences between restaurant reviews published in the United States and in Brazil. Secondly, we intend to provide the reader with alternatives to deal with those differences. Drawing on corpus linguistics methodology (McEnery \& Hardie, 2012; Stefanowitsch, 2020), we conducted a quantitative analysis of a comparable corpus to show broader, macro textual characteristics of the genre restaurant review in Brazilian Portuguese and North American English. We then proceeded with a qualitative, manual analysis of keywords retrieved from those texts and discussed possibilities on how to deal with the cultural differences revealed by terms and collocations in both languages regarding the characteristics of the intended audience.

Our study, which follows this introduction, is based on text genre (Bhatia, 1993; Marcuschi, 2002) and functional translation (Nord, 2006, 2012), as explained in the next section. Corpus linguistics (McEnery \& Hardie, 2012; Stefanowitsch, 2020) underlies the methodology applied to the investigations of the texts. The analysis of data (Section 8) is followed by a Discussion (Section 9). Concluding remarks close this article.

\section{Genre Restaurant Review and Translation}

Nowadays, consumers are faced with countless options for any service or product they are looking for. From buying a cell phone or a trip, choosing a movie or a meal, people may count on the opinion of acquaintances, strangers, or professionals before deciding. Defined by Blank (2007, p. 1) as "a mechanism through which social status is made publicly visible," reviews present an evaluation of a product to help consumers make conscious choices.

Mainly driven by social networks, blogs, and YouTube ${ }^{\circledR}$ channels, in addition to other vehicles, opinions on movies, hotels, appliances, restaurants, etc. are, even in real-time, shared on a regular basis. Tripadvisor ${ }^{\circledR}$ alone has published over 800 million users' feedback on accommodations and restaurants ${ }^{5}$ and has been used as a source for academic research (see, for example, Fuchs, 2018, for an analysis of hotel reviews posted by Brazilian and North American travelers on that website). Yelp ${ }^{\circledR}$ was the source of retrieval of over 600,000 users' restaurant reviews in the study carried out by Li et al. (2020) on emotional intensity in this genre. In the face of such an availability of evaluations, we could question the relevance of published reviews, written by professionals - usually journalists - to comprise the study corpus used in this research.

Despite their popularity, users' evaluations may not provide evidence to justify their opinion whereas reviews by professional writers should conform to a series of requirements, usually stated by the publication they adhere to. Hence, despite selling like hotcakes and reaching an enormous audience, laymen's reviews may lack the credibility that many consumers search for before choosing from the numerous offers at their disposal. To satisfy a hungry audience that desires more than a peer's opinion or advertisements before making a decision, many newspapers, magazines, and specialized

5 Source: https://tripadvisor.mediaroom.com/usabout-us. Accessed January 31, 2021. 
web pages still publish experts' reviews, like the ones that compose our corpus.

Blank (2007) identifies two types of professional reviews: procedural and connoisseurial. Mostly applied to durable goods, procedural reviews rely on a set of methods to evaluate the performance of a product, resulting in scores. Connoisseurial reviews, on the other hand, consist basically of running texts through which critics, understood as writers who convey credibility, due to talent, experience, and training, are entitled to share their impressions on a product, summarize the features of the item under evaluation, and attempt to persuade the reader to believe them by presenting arguments.

Despite their inevitable degree of subjectivity, connoisseurial reviews must conform to a range of standards to approach the readers. We believe that it is precisely the adherence to standards that leads the publications to gain the readers' confidence and fidelity, thus stimulating those vehicles to continue publishing reviews on a regular basis - even in different fluxes, according to each target audience.

According to Blank (2007, p. 7), regardless of the product they refer to, connoisseurial reviews describe and evaluate a certain item or experience through lean and intense writing, basically aimed at answering two questions: "What is it?" and "Is it any good?". In this sense, connoisseurial restaurant reviews share characteristics with other types of reviews - for example, movie, theater, book reviews-, as they all describe and evaluate a product or an experience. However, despite sharing characteristics that are recognizable by readers from different cultures and language communities, restaurant reviews expose peculiarities of the culture they are inserted in and vary depending on the means of publication and the target audience.
Unlike other kinds of reports — news, for example-, reviews not only summarize the features of a product but also justify the critic's overall impression. Hence, more than explaining what the product is and concluding if it is good or not, the critic presents arguments to convince the reader. Thus, to the two questions aforementioned regarding the purpose of reviews, we could add a third one: Why?

In this study, we concern ourselves basically with aspects of Brazilian and American connoisseurial restaurant reviews (henceforth, restaurant reviews or simply reviews) revealed by recurring linguistic items, or their absence, in one of the languages/cultures, and their impact for translation.

\section{Restaurant Review: A Genre of its Own}

Bhatia (1993) defines genre as "a recognizable communicative event characterized by a set of communicative purpose(s) identified and mutually understood by the members of the professional or academic community in which it regularly occurs" (p. 49). Although they are influenced by factors such as content, form, intended audience, medium, etc., texts belonging to a certain genre share internal structures and characteristics that enable effective communication to take place. More than making individual choices to write more effectively, depending on the purposes of the production, the professional writer always adheres to external factors (Bhatia, 1993), including the publisher, space, readership, socio-cultural contexts, etc. Nevertheless, those strategies, which Bhatia refers to as "non-discriminative," do not interfere with the communicative purpose of the genre (Bhatia, 1993, p. 59).

Marcuschi (2002) claims that we communicate through a text, just as we communicate 
through a text genre. The author understands that genres are functionally integrated into the cultures in which they are developed more for their communicative, cognitive, and institutional functions than for their linguistic and structural peculiarities. In other words, verbal communication is only possible through text genres, but those genres do not follow a cooking recipe ready to be used. Instead, they are adaptable, flexible, mutable, and dependent on the historical, social, and cultural context of a certain community.

For Pudlowski (2012), although Grimod de La Reynière (1758-1838) is considered the pioneer in describing and evaluating restaurants right after those establishments emerged in the $18^{\text {th }}$ century Paris, it was not before the turn of the $20^{\text {th }}$ century that gastronomy, and hence its evaluation, was consolidated. At that time, tire manufacturer Edouard Michelin devised a guide that intended to provide drivers with information on where to fuel, eat, stay overnight, in addition to other useful tips for those traveling around France. The data for the first Michelin ${ }^{\circledR}$ issues published were gathered through information from the brand's representatives who crossed the country to work, but the first paid evaluators would appear in France only in 1933 (Pudlowski, 2012).

In the United States, restaurant reviews have an even longer tradition. The first New York Times news article on gastronomy is claimed to have been published in $1859^{6}$, and since then, this newspaper has been home for many of the world's most famous food critics, such as Ruth Reichl and Craig Claiborne. In Brazil, on the other hand, restaurant reviews are not as traditional. Brazilian food critic Arnaldo Lorençato argues that this genre started being published

6 Source: https://kottke.org/07/09/first-ny-times-restaurant-review-circa-1859. Accessed January 31, 2021. on a regular basis here only in 1966 . Hence, it is the youngest if compared to literature and theater reviews, for example (Lorençato, 2012).

In his foreword to the Brazilian Portuguese translation of Pudlowski's (2011) À quoi sert vraiment un critique gastronomique?, Lorençato (2012, p. 12) states that gastronomy, formerly considered "the kitchen of journalism," has been gaining more and more space - although today, the irony would no longer have the expected effect, as the kitchen has gained the status that previously belonged to the living room in several homes; but the critic complains that restaurant reviews have become a fad, as inexperienced users, called by Lorençato "cell phone critics" (Instagram, 2020) ${ }^{7}$, simply comment on their personal experiences, reducing evaluations to "I liked it" or "I didn't like it" (Lorençato, 2012).

Blank (2007) would probably agree with the Brazilian critic's reasoning, as the American sociologist believes that a successful review should make the readers feel as if they were having that experience themselves, and to do so, a connoisseurial reviewer should have the ability to write well, implying "energetic, forceful prose that readers will listen to and be persuaded by." (Blank, 2007, p. 32). We cannot predict the future of professional reviews, as nowadays restaurateurs prefer to welcome digital influencers, who usually upload a photo or video to their Instagram story with compliments to the house in exchange for a meal, a sponsorship, or a sum of money.

In general, contemporary restaurant reviews consider basically three elements of the dining experience: food, ambience, and service (Schira, 2015). Naturally, the element on which the reviewer focuses more heavily is food, evaluated

7 "críticos de celular". 
according to taste, texture, smell, and presentation. Ambience is judged through the quality of the surrounding items - temperature, comfort, utensils, furniture, etc.- , whereas service entails the interaction between the client and the staff. Apart from those fundamental elements, the reviewer also considers price performance, accessibility, and location, among other culture-related features as we will discuss later.

Pudlowski (2012, p. 53) defines a food critic as "a humble scribe of pleasures, a faithful investigator of concerns, a scribe of exuberant parties, the invisible banquet guest" 8 whose main role is to prevent the reader from "walking in the wrong door" (Pudlowski, 2012, p.45) ${ }^{9}$. Above all, he adds, the critic's gift is to know how to report (i.e., a good critic chooses the right words to make the reader's mouth water, to make him or her feel like visiting a certain place or not). Compliments and criticisms should be justified. Modern restaurant reviews should be fun and enjoyable to attract readers, and hence, customers to the restaurants (Pudlowski, 2012). As such, he compares the food critic to a chronicle writer, whose rhetorical strategies are paramount to the success of the task.

As any well written article, a restaurant review starts with an appealing title, which highlights the meaning of the text and plays a major role in the reader's decision to read the text or not. To attract the reader's attention, food critics imprint their own style when titling, as no fixed rules are established. As starters, titles evoke interactivity, intertextuality, metaphor, colloquialism, pun, multiple meanings, and humor (Amaral, 2006). But different from a news article intended to objectively inform the reader about an event, restaurant reviews are crowded with subjective

\footnotetext{
8 " [...] um humilde escriba de prazeres, um investigador fiel de inquietações, um escrivão de festas exuberantes, o convidado invisível de banquetes".

9 "se engane de porta".
}

markers, opinion adjectives, figurative language, and colloquialism.

Brazilian and American restaurant reviews' frequent readers would certainly agree that the characteristics stated above about texts and critics permeate the genre in both languages and cultures. Nevertheless, when contrasted more closely, those texts also reveal discrepancies, as the fundamental questions raised in restaurant reviews - What is it? Is it any good?, and Why? - are answered differently. And those differences should be accounted for when this genre is functionally translated (or even written) in one of these languages. Before we present those differences and suggest how they should be approached in the translated text, a brief account of the concepts underlying functional translation seems appropriate.

\section{Functional Translation of Restaurant Reviews}

Concerning specialized texts, Nord (2006) claims that there is no single method to accomplish a translation task. Rather, it is the translation purpose that will determine the method adopted. When the text achieves its aim(s), that is, when it works for the target receiver in a way the sender expects it to work, translation is referred to as functional (Nord, 2006, 2012). Hence, "[f]unctionality is not an inherent quality of a text" (Nord, 2006, p. 31), but an aspect attributed to it by the receiver. In this sense, the translator needs not only to make conscious choices to achieve the expected function of the text but also count on the audience's cooperation to make sense of them. Moreover, Nord (2006) argues that it is the translator's task to combine new and known information to produce an appropriate text.

When considering a functional approach to the translation of restaurant reviews, the translator needs to keep in mind not only the linguistic 
characteristics of the genre (appealing title, convincing arguments, use of creative and figurative language, etc.) but also the specificities of this genre when it is aimed at different audiences. But before presenting linguistic and cultural differences retrieved through the investigation of a corpus of American and Brazilian restaurant reviews, we will discuss an aspect that is essential for the functional translation of any text genre: conventionality.

To get the most out of the communication, the reader expects to recognize features in the standard texts previously observed in other samples of the same genre, that is, the texts belonging to a certain genre should reveal characteristic conventions. According to Tagnin (2013), conventionality occurs at three linguistic levels, namely (i) syntactic - related to the way the elements are grammatically combined; (ii) semantic in relation to the meaning of the elements that make up sentences, collocations, idiomatic expressions, etc.; and (iii) pragmatic - concerning the interaction between participants in the communicative act. It is important to emphasize that linguistic conventions are enshrined in usage, not always adhering to a conceptual logic. Therefore, conventionality relates to how the genre is recognized in a given language and entails that linguistic units have previously been stored in the speaker's or reader's memory.

In this sense, corpora, as understood according to the approach underlying corpus linguistics, not only help translators to identify peculiarities of the source texts, but they also assist them in finding solutions to be used in the target language, as text analysis tools enable that data indicating patterns of conventionality are quantitatively retrieved (Stewart, 2000) to be further manually analyzed by the researcher.

In accordance with what was stated above, we chose connoisseurial reviews to compile a corpus to be used as a source of terminology retrieval to comprise a bilingual English-Portuguese glossary aimed at translators and writers of culinary texts, especially reviews and menus. A detailed explanation of the corpus compilation and the construction of the glossary can be found in Rebechi et al. (2021). In the next section, dedicated to the methodology, we limit ourselves to information deemed important for the comprehension of the items retrieved and more thoroughly analyzed in this work.

\section{Methodology}

The Internet, driven by social networks, became a means of opinion exchange, and restaurants are only one of the topics lay people write about. These evaluations may be a source for research on sentiment and discourse analysis, for example; but as nonprofessional reviews need not conform to standards, varying from unjustified opinions to well-grounded texts, they were not considered appropriate as a source of patterned terminology retrieval. Published connoisseurial reviews, on the other hand, evoke credibility, as they have supposedly been adjusted to publishing standards. Hence, they were chosen to comprise our study corpus.

In order to identify the recurring characteristics of Brazilian and American restaurant reviews, we adopted an empirical approach to perform the analysis of the authentic texts. Next, we give a brief overview of corpus linguistics, the methodology used in this study, followed by an account of the corpus investigation.

\section{Corpus Linguistics}

According to Stefanowitsch (2020, p. 50), corpus linguistics encompasses a variety of definitions, including "the investigation of linguistic phenomena on the basis of computer-readable linguistic corpora using corpus analysis software" (emphasis in the original), which suits this study. 
According to this approach, a corpus is a collection of samples of language use that entails three fundamental properties: authenticity (real-life language produced for the purpose of communication, not investigation); representativeness (the corpus should encompass different manifestations of the language or genre it is meant to represent, seeking balance); and size (the corpus is expected to contain sufficiently large samples of a genre). As for the last property, we consider it doubly troublesome. Firstly, it seems impossible to devise an ideal size of a corpus as continuous advances in technology enable the construction of larger and larger corpora. Secondly, except for the study of a language as a whole, represented by samples from different genres, registers, and typologies, smaller corpora can reveal terms and patterns that can properly inform research.

Advantages of small corpora are addressed by Koester (2010), who claims that, as long as they are specialized, small corpora will properly serve research as they are usually compiled and analyzed by the same person, who is probably familiar with the context, and such familiarity enables the qualitative analysis to complement the quantitative findings. After all, it is the purpose of the study that will determine the ideal corpus size, provided that the corpus is representative of a domain. To that end, the corpus should be designed according to well-defined criteria.

As regards specialization, Flowerdew (2004, p. 21) suggests six parameters to be considered in the compilation of a corpus. Adapted to our research, the parameters encompass the following:

- genre: restaurant reviews;

- $\quad$ specific purpose for compilation: to extract simple and compound keywords proper of the genre;

- contextualization/communicative purpose of the texts: describe, evaluate, and present arguments;
- type of text/discourse: informative/ persuasive;

- subject matter/topic: description and evaluation of food, ambience, and service;

- variety of language: standard written American English and Brazilian Portuguese.

With these features in mind, we compiled a comparable corpus of restaurant reviews.

\section{The Study Corpus}

As a previous criterion, we intended to gather only reviews published online in newspapers and magazines to guarantee that the texts had been written by professionals, usually journalists. However, we noticed that the texts in Portuguese were much shorter than the ones in English (this difference will be discussed in detail below). Moreover, connoisseurial reviews are not easily found in Brazil. Hence, it would be difficult to reach 400,000 tokens in each language, a number we considered reasonable to conduct the research. Therefore, we decided to make an exception to the previously specified criteria about authorship and included the content of one web-based community in each subcorpora: Destemperados ${ }^{10}$, in the Brazilian Portuguese subcorpus, and CTbites ${ }^{11}$, in the American one. Despite not being written by professionals, but built by and for people who love food, as the authors describe themselves, the posted texts undergo revision. Destemperados reviews are published by a broadsheet newspaper (Zero Hora), and CTbites reviews are submitted to an editor and contributors before publication. The corpus was compiled from 2016 to 2019. Table 1 summarizes the comparable corpus.

10 https://gauchazh.clicrbs.com.br/ destemperados/ultimas-noticias/

11 https://www.ctbites.com/ 
Table 1. The Study Corpus

\begin{tabular}{|c|c|c|c|c|}
\hline & Newspapers and magazines & $\begin{array}{l}\text { Web-based } \\
\text { communities }\end{array}$ & $\begin{array}{l}\mathrm{N} .{ }^{\circ} \text { of } \\
\text { texts }\end{array}$ & $\begin{array}{c}\mathrm{N} .{ }^{\circ} \text { of } \\
\text { tokens }\end{array}$ \\
\hline $\begin{array}{l}\text { Brazilian } \\
\text { Portuguese }\end{array}$ & $\begin{array}{l}\text { Folha de São Paulo, Paladar, O Globo, } \\
\text { Extra, Super Notícia, Veja, Veja sp, Veja вн, } \\
\text { Veja Curitiba, Prazeres da Mesa }\end{array}$ & $\begin{array}{l}\text { Destemperados } \\
\text { (published by } \\
\text { Zero Hora) }\end{array}$ & 1,266 & 421,904 \\
\hline $\begin{array}{l}\text { American } \\
\text { English }\end{array}$ & $\begin{array}{l}\text { Chicago Tribune, Daily News, Dallas } \\
\text { News, Detroit Free Pass, Greenwich Times, } \\
\text { Houston Chronicle, LA Times, Newsday, } \\
\text { New York Times, New York Post, Tampa Bay } \\
\text { Times, The Arizona Republic, The Boston } \\
\text { Globe, The Miami Herald, The Washington } \\
\text { Post, usA TODAY }\end{array}$ & CTbites & 441 & 415,615 \\
\hline
\end{tabular}

Both subcorpora were submitted to the corpus tool Sketch Engine (henceforth, SE) (Kilgarriff et al., 2014). Using English Web 2013 (enTenTen13) and Portuguese Web 2011 as the reference corpora, we retrieved 5,373 single and compound keywords in English and 4,892 in Portuguese which recurred at least five times. The words with the highest Keyness in English and in Portuguese are shown in Tables 2 and 3, respectively.

As we were interested in terms and collocations frequently used in restaurant reviews as a genre and did not intend to privilege any special cuisine, the lists of keywords were manually analyzed so that names of ingredients

Table 2. First 20 Simple and Compound Keywords in English in Decreasing Order of Keyness (Score)

\begin{tabular}{|c|c|c|c|c|c|}
\hline \multicolumn{3}{|c|}{ Simple keywords } & \multicolumn{3}{|c|}{ Compound keywords } \\
\hline Term & Score & Frequency & Term & Score & Frequency \\
\hline chile & 216,540 & 190 & wine list & 140,510 & 92 \\
\hline taco & 186,580 & 262 & full bar & 124,840 & 74 \\
\hline braise & 176,300 & 140 & pork belly & 123,910 & 74 \\
\hline aioli & 170,120 & 96 & executive chef & 92,840 & 62 \\
\hline fried & 166,100 & 361 & dining room & 92,630 & 254 \\
\hline crispy & 156,920 & 192 & fried chicken & 85,350 & 67 \\
\hline pickled & 150,550 & 123 & open kitchen & 72,170 & 43 \\
\hline sauce & 141,340 & 929 & blue cheese & 71,640 & 43 \\
\hline entree & 140,090 & 139 & daily news & 69,430 & 56 \\
\hline dumpling & 137,750 & 133 & short rib & 68,680 & 35 \\
\hline grilled & 136,570 & 253 & goat cheese & 67,480 & 45 \\
\hline patty & 125,990 & 117 & beef patty & 65,380 & 33 \\
\hline burger & 125,150 & 349 & tomato sauce & 61,350 & 49 \\
\hline broth & 121,610 & 177 & pastry chef & 60,820 & 39 \\
\hline noodle & 117,180 & 272 & red onion & 55,380 & 35 \\
\hline appetizer & 114,240 & 185 & pork chop & 52,070 & 29 \\
\hline cilantro & 111,090 & 94 & fried egg & 49,670 & 27 \\
\hline ramen & 108,780 & 90 & noise level & 48,150 & 35 \\
\hline vinaigrette & 107,910 & 75 & tasting menu & 45,410 & 25 \\
\hline diner & 106,870 & 221 & food truck & 45,140 & 32 \\
\hline
\end{tabular}


Table 3. First 20 Simple and Compound Keywords in Portuguese in Decreasing Order of Keyness

\begin{tabular}{|c|c|c|c|c|c|}
\hline \multicolumn{3}{|c|}{ Simple keywords } & \multicolumn{3}{|c|}{ Compound keywords } \\
\hline Term & Score & Frequency & Term & Score & Frequency \\
\hline dinners & 340,160 & 193 & pagamento cartões & 421,270 & 225 \\
\hline cartões & 337,510 & 451 & $\begin{array}{l}\text { pagamento cartões } \\
\text { de crédito }\end{array}$ & 415,670 & 222 \\
\hline electron & 335,650 & 226 & rede shop & 384,250 & 206 \\
\hline lugares & 239,330 & 233 & serviços acesso & 383,910 & 205 \\
\hline drinque & 202,490 & 241 & cartões de débito & 360,210 & 233 \\
\hline chef & 193,860 & 866 & acesso wireless & 301,100 & 190 \\
\hline valet & 173,110 & 107 & american express & 260,400 & 203 \\
\hline crocante & 170,830 & 201 & acesso wireless ar & 258,770 & 138 \\
\hline risoto & 160,090 & 206 & wireless ar & 258,770 & 138 \\
\hline sobremesa & 146,050 & 630 & preço de r & 251,290 & 134 \\
\hline cardápio & 146,030 & 999 & preço atér & 159,770 & 85 \\
\hline mastercard & 144,380 & 234 & $\begin{array}{l}\text { serviços acesso } \\
\text { wireless }\end{array}$ & 146,690 & 78 \\
\hline bistrô & 139,170 & 154 & carta de vinhos & 118,880 & 85 \\
\hline empanar & 132,410 & 130 & doce de leite & 117,800 & 108 \\
\hline hambúrguer & 130,510 & 177 & pratos principais & 98,260 & 90 \\
\hline farofa & 128,460 & 212 & $\begin{array}{l}\text { estacionamento } \\
\text { lugares }\end{array}$ & 96,260 & 51 \\
\hline vinagrete & 125,470 & 104 & cartões de crédito & 94,830 & 233 \\
\hline ceviche & 121,320 & 74 & $\begin{array}{l}\text { serviços acesso } \\
\text { wireless ar }\end{array}$ & 92,530 & 49 \\
\hline
\end{tabular}

and dishes were removed. Proper names and keywords that recurred in only one of the sources were also ignored to avoid one single critic's or source's idiosyncrasies.

The keywords in both languages were paramount for the retrieval of functional equivalents which are essential to guarantee conventionality when translating or writing restaurant reviews. Moreover, through the keyword lists, we were able to provide the English entries with translation equivalents which are not always found in reference works. While assembling the glossary, we realized that although we had compiled a comparable corpus comprising texts of the same genre (restaurant reviews) withdrawn from similar sources (publications in magazines and newspapers) and followed well-defined criteria, single and compound keywords retrieved from the automatic processing of the texts revealed differences in the texts written originally in that language pair that go far beyond linguistic differences. In face of this scenario, we raised distinct features which should be taken into account when translating or writing restaurant reviews according to the functional approach (Nord, 2006, 2012), and that should at the same time be regarded as conventional (Tagnin, 2013) in the target language. 


\section{Analysis}

During the corpus compilation and analysis, we found a multitude of similarities as well as differences between Brazilian and American reviews. In this section, we will discuss the differences and their impact on translation and production of restaurant reviews. These differences are divided into macro and micro textual aspects, here understood, respectively, as broader issues raised during compilation and automatic investigation of the corpus, and elements observed through manual analysis of the keywords. These topics are detailed below.

\subsection{Macro Textual Aspects}

Before detailing the linguistic features characteristic of American and Brazilian restaurant reviews, which will be addressed below as micro textual aspects, we will point out more general elements that differentiate both sets of reviews. According to what was previously stated, we compiled our comparable subcorpora following well-defined criteria so that we could gather meaningful samples of the same genre - restaurant reviews - to build a bilingual Brazilian Portuguese-American English glossary in this domain. During the compilation, we already noticed that restaurant reviews are approached differently by Brazilian and American publications. The availability of texts is the first difference.

While in the USA most newspapers and magazines have a section dedicated to food and restaurants, including reviews, in Brazil the subject is not a centerpiece. In addition, a first attempt to compile the same number of reviews in both languages required amendments, as the texts aimed at the American audience are on average three times larger than their Brazilian counterparts, resulting in an imbalance of the subcorpora regarding the words/tokens.
This expressive difference may have at least two explanations: (i) the genre is more traditional in the United States, and as such, it occupies more space in American publications; and (ii) American reviews are more detailed than the Brazilian ones. Concerning the first hypothesis, drawing on sociological research, Blank (2007) concludes that over half of the American population reads restaurant reviews. Among upper-middle-class professionals, this number is approximately $100 \%$. Hence, we assume that the habit of reading reviews is directly associated with purchasing power. Given that the Americans' income is about five times higher than the Brazilians, ${ }^{12}$ the former are unsurprisingly more interested in restaurant reviews. In addition, Blank (2007) argues that many Americans read reviews not necessarily with the intention to visit the restaurant, but especially to have a topic to talk about. As this genre has more tradition in the USA, many newspapers and magazines obviously publish restaurant reviews on a regular basis. With respect to the coverage of restaurant reviews for Brazilians, we could not find academic, updated information about this reading habit in the country.

Regarding their length, reviews are usually described as concise texts. According to Blank (2007), reviewers writing for American newspapers need to accomplish their aims using up to one thousand words, resulting in lean writings, as " $t]$ he review is an intense, condensed description and evaluation of the reviewer's experience" (p. 45). This number corroborates our findings, as the quantitative analysis of the corpus in English demonstrated that the texts have, on average, 942 words/tokens. Nevertheless, what is considered concise and lean in one language and culture may not correspond to the same characteristics in another. As we

12 In 2019, American constant gross domestic power per capita was US\$66,064 and Brazilian, US\$8,717. Retrieved from https://fred.stlouisfed.org/, access: January 31, 2020. 
saw above, Brazilian restaurant reviews tend to be around three times shorter than the American ones, with 333 words/tokens on average.

According to Katan (1999, p. 177), "individuals, groups, and cultures (and at different times) have differing priorities with regard to how much information (text) needs to be made explicit for communication to take place." Cultures that rely heavily on prior knowledge, thus requiring less text to convey information, are referred to as high-context, whereas low-context cultures are expected to demand more explicitness since common knowledge is usually insufficient to guarantee that proper communication takes place. In a classificatory cline, Katan shows Latin American cultures as more high-context than Americans, which may also explain the briefness of Brazilian restaurant reviews when compared to their American counterparts. Empirical contrastive studies of Brazilian and American obituaries (Rebechi \& Moura, 2018), hotel descriptions (Navarro, 2011), and hotel evaluations (Fuchs, 2018) corroborate these conclusions. Obviously, the length of the texts will unveil other differences in texts pertaining to the same genre in different languages and cultures.

During the quantitative analysis of the corpus, SE revealed characteristics of both subcorpora that were later confirmed through manual analysis. One of these features relates to the use of word classes, more specifically adverbs and adjectives. As reviews are characterized by carrying a high degree of opinion, it comes as no surprise that adjectives are massively used in this genre. Indeed, adjectives account for 31,856 of the total number of tokens in Portuguese, and 43,363 in English. Nevertheless, the adjectives used vary much more in the English subcorpus, with 5,733 types, compared to 2,762 in Portuguese.

Adverbs are also worth mentioning. Despite being balanced in relation to overall usage
$-18,855$ in English and 19,998 in Portuguese (4.55\% and $4.44 \%$ of the total number of tokens) - the number of types differs significantly: 355 in English and 170 in Portuguese. In addition, when we compare the number of adverbs ending in -ly and its prima facie translation equivalents in Portuguese, -mente, the difference is even bigger - 217 items in English are used 4,629 times, whereas 37 items of this kind in Portuguese occur only 554 times. In other words, adverbs ending in -ly account for $24.51 \%$ of the total number of adverbs in English, whereas adverbs ending in -mente represent $3.6 \%$ of the adverbs in Portuguese. A closer analysis of the use of this word class in both subcorpora demonstrated that a recurring combination such as "perfectly fried" would be conventionally rendered as frito(a) à/com perfeição or bem fritinho(a), that is, with an adverbial phrase and not with the adverb perfeitamente. This conclusion is in line with Moraes (2015), whose analysis of parallel corpora of recipes and legal agreements translated from English into Portuguese demonstrated that not all adverbs ending in -ly are rendered as adverbs ending in -mente, and that the translation of adverbs by their cognate forms disregarding their contexts may render an unconventional expression.

Another characteristic of Brazilian restaurant reviews is the recurring use of nouns, adjectives and adverbs in the diminutive with the suffix -inho(a) not to refer to small-sized items, but rather to manifest the speaker's affection and positive opinion towards the quality of the item under analysis. Actually, this colloquialism may denote emphasis, as the words ending in -inho(a) entail the idea of intensity and precision. Some examples are the keywords gostinho, cheirinho, quentinho, levinho, fresquinho, etc., used by critics to convey a positive impression towards the senses of taste, smell, temperature, lightness, and freshness, respectively. 
In view of these and other aspects that were highlighted through the (semi)automatic analysis of the study corpus, we moved on to a careful look at the keywords in context to manually find functional and conventional equivalents for terms and collocations typical of restaurant reviews in Portuguese and in English - while discarding those that were not considered typical of the genre.

\subsection{Micro Textual Aspects}

From the keywords automatically retrieved by SE in both subcorpora, we proceeded to the manual analysis of the simple and compound keywords and collocations selected as entries and subentries, as well as of their functional equivalents, which along with examples, definitions, comments and cross-references comprise the English-Portuguese glossary of restaurant reviews. It seems important to emphasize that the methodology applied is similar to the one described in Rebechi et al. (2021), which details the construction of the Portuguese-English glossary concerning the types of terms selected and the ones excluded. Nevertheless, it cannot be said that we simply reversed the glossary, as we considered the specificities of each subcorpus to decide on the entries, as we will explain below.

Drawing on Johansson (2007), we explored a bilingual corpus in search for correspondences (i.e., similarities across languages that may be used as equivalents). Equivalents in Portuguese were retrieved, when available, from the list of simple and compound keywords retrieved with SE. This process was important so that we could provide the best functional translation (Nord, 2006, 2012), as our aim was to compile a glossary with conventional Portuguese equivalents for the English entries.

During the task of searching for functional equivalents in Portuguese for the selected simple and compound keywords in English, we observed a number of specificities of each subcorpus, which hindered the identification of matches. We classified those mismatches in five categories, namely (i) a myriad of terms, (ii) detailing, (iii) technicality, (iv) figurative language, (v) implicitation vs. explicitation, and (vi) culture bumps, which will be discussed below, along with our proposals of translation equivalence.

\subsubsection{A Myriad of Terms}

Unlike other specialized texts that seek terminology consistency, restaurant reviews contain distinct terms and collocations to refer to the same concept. Therefore, the glossary was constructed to offer the user various possibilities of translation equivalents, when appropriate. For example, the entry delicious, which also refers the user to the synonyms delectable, luscious, toothsome, yummy, heady, and finger-licking good, presents as translation equivalents delicioso, uma delícia, de comer rezando, de lamber os beiços/dedos, de raspar o prato, dos deuses, and divino, so that the translator or writer may vary ways of indicating that a dish is full of flavor.

Different from specialized texts that seek terminological consistency, restaurant reviews are creative texts, resembling literature in what regards the use of varied ways of referring to similar concepts. Through the manual analysis of keywords, we realized that American reviews show a much wider variety of terms and structures to refer to similar concepts than their Brazilian counterparts. As an example, we identified that dab, hint, jolt, kick, punch, smidgen, spin, sprinkle, touch, whiff, whisper, and zing are used to refer to a small but noteworthy amount of an ingredient, and can be translated as toque, pitada, pincelada and pouquinho. Blah, bland, dull, flavorless, ho-hum, pedestrian, and tepid can be rendered as sem graça, insosso, and sem sabor. 
Different structures to convey similar meanings are also typical of the American reviews. The key phrases -studded/studded with, -flecked/ flecked with, -strewn/strewn with, and -sprin$\mathrm{kled} /$ sprinkled with, in addition to dotted with, scattered with and speckled with could be translated as salpicado com and polvilhado com, the only possibilities of translation equivalents identified among the Portuguese keywords.

We believe that a reference material designed to provide equivalents for terms and phrases characteristic of restaurant reviews should provide readers with as many options as possible, paying attention to the particularities of the genre in both languages so that the translator or writer produces a text which is perceived as conventional by the target audience.

\subsubsection{Detailing}

As aforementioned, American restaurant reviews are on average three times longer than their Brazilian counterparts. Such a large difference obviously goes beyond language-related specificities. By comparing both keyword lists, we concluded that the discrepancy in size accounts for the degree of details provided by the American critics.

According to Blank (2007), critics tend to evaluate restaurants by targeting three major categories: service, décor, and food. The first describes how well the staff is prepared in terms of receiving customers and knowing details about the menu; décor includes elements such as cutlery, lighting, interior design, chairs, and tables; and food comprehends a descriptive evaluation of what the critic could try. Even though those categories are part of basically any restaurant review, published in Brazil or in the United States, they are not necessarily given the same emphasis, and the difference relies on how each culture approaches these categories.
Regarding the food, the element to which more attention is given, the analysis of the keyword lists demonstrated that both Brazilian and American reviews describe the items served (i.e., the final product) according to their taste, texture, temperature, presentation, etc. Nevertheless, the preparation process is given much more emphasis in the English texts. One of the signs which corroborates this finding is the high number of keywords referring to cooking utensils in the English subcorpus when compared to its Portuguese counterpart. Portuguese equivalents for cast-iron skillet and wok-tossed/wokfried, for example, could not be found in the corpus, although they do exist in Brazilian Portuguese - frigideira de ferro, salteado/frito na wok.

Detailing the décor is also an important feature of American reviews. References to the type of tiles (e.g., white subway tiles) and the type of wood used on the tables (e.g., bare wood table, sturdy wood table, handmade wooden table, etc.) are almost exclusive to the English texts. In Portuguese, there is hardly any reference to the material the furniture is made of -mesa de madeira [wood(en) table].

The critic's opinion of the service provided by the restaurant is also more frequently justified in the English texts. For example, "And [X] is strong on service, thanks to experienced waitstaff and well-trained newcomers. If only more restaurants paid this much attention to service, from the greeting down to packing up leftovers for customers." 13 In the Brazilian texts, service is usually simply qualified as good, attentive, fast, etc., but no detailed justification is provided. See the following example: A casa tem tudo o que me faz vibrar com um restaurante: tradição $e$

13 Adapted from https://www.usatoday.com/story/ entertainment/dining/carol-deptolla/2016/07/22/ restaurant-review-crawdaddys-reopening-has-itsups-and-downs/87471700/. Accessed 19 July, 2021. 
consistência, bom atendimento e excelente cozinha. [The house has everything that thrills me in a restaurant: tradition and consistency, good service and excellent food. $]^{14}$

The difference in the level of detailing, and therefore, the length of texts observed in American and Brazilian reviews, is in line with other studies, as presented above. As such, when translating restaurant reviews from English into Portuguese, professionals should keep in mind how much text the Brazilian reader is willing to read and, hence, consider making implicit information that is assumed by, or irrelevant to the target audience.

\subsubsection{Technicality}

By detailing the preparation process of the dishes, American reviews unveil another characteristic: the degree to which those texts resort to more technical terms than their Brazilian counterparts. One example is the keyword blanch, a term that refers to the process of briefly boiling vegetables or fruits and putting them into cold water shortly after in order to freeze them and preserve their nutrients. In Brazilian Portuguese, this technique is known as branqueamento, a term with a single hit in the subcorpus. The same applies to the keyword smoker, whose prima facie equivalent, defumador, appears only once in the Brazilian subcorpus.

Another example of technicality in the American English texts - but absent from the Brazilian reviews - is the adjective compressed, preceding names of fruits and vegetables. Vacuum compressing fruits and vegetables is a modernist technique that can give porous foods a translucent appearance and a different texture.

14 Retrieved from: https://www.portalgastronomix. com.br/gambrinus-tradicao-em-lisboa/. Accessed 19 July, 2021.
An equivalent term was not found in the Brazilian subcorpus.

Ramekin, a small ceramic bowl in which food is usually baked and served, is also exclusive to the English subcorpus. Although the term is known to Brazilian gourmets, critics seem to prefer the generic potinho (de vidro) [small (glass) bowl]. Still another example of the difference in relation to technicality level regards the kinds of cuts of meat, poultry, vegetables, etc. The subcorpus in English revealed a number of differing results - minced, (finely) chopped, cubed, diced, julienned, etc.- indicating the precision of the processes, whereas in Portuguese, the diminutive is once again the preferred strategy to indicate the welcome results: (bem) picadinho for the first four cuts, and cortado fininho for the last one.

These findings corroborate Rebechi and Moura's (2017) analysis of phraseologies in Brazilian recipes published in English and in Portuguese. The authors concluded that recipes written in English resort to more technical terms than their counterparts aimed at the Brazilian audience. They observed that "the use of more technical terms in cooking phraseology in English is considered acceptable by American nonprofessional cooks, but not by their Brazilian counterparts, as they may interpret it as excessive use of technicality" (p. 110). And this preference should be taken into account during translation, instead of simply rendering terms with their prima facie equivalents.

\subsubsection{Figurative Language}

Here understood as a word or phrase used "to describe one thing in terms of another" (Newmark, 1988, p. 104), figurative language has raised frequent discussions in Translation Studies as researchers are concerned with the (im) possibility of transferring metaphors, idioms, and other words and phrases that deviate from their 
denotative meanings. Rendering what Newmark (1988) generalizes as metaphors involves not only translatability itself, but also the elaboration of translation strategies. For the author, the debate stems from the fact that metaphors are traditionally understood as a mere linguistic expression used to embellish the text, and as such, they should be rendered with an equivalent expression in the target text.

Such a superficial view of this communicative resource expressed through language was questioned in cognitive linguistics by Lakoff and Johnson (1980), who stated that metaphors (i) are property of concepts, not words; (ii) provide a better understanding of the concepts; (iii) are not necessarily based on similarity; (iv) are commonly used by everyone in real life situations, and, hence, are not restricted to creative texts; and (v) consist of an inevitable process of human reasoning. In short, for cognitivists, metaphors encompass the entire cultural reality and are an essential phenomenon for understanding the world (Kövecses, 2010). A detailed discussion of conceptual metaphors, as well as a distinction between figurative and literal language, is beyond the scope of this study. We deal here simply with the resulting metaphorical linguistic expressions, which recur in authentic language and are observed, albeit at different levels, in all textual genres.

Although some concepts are manifested in similar ways in different languages and cultures, resulting in what Kövecses (2010) calls universal metaphors, it would be naïve to imagine that metaphors were interchangeable in different languages and cultures and that they could therefore be rendered in the translated text through literal translation. Sato (2015) also discusses the linguistic and cultural barriers that hinder the transfer of figurative language from one language to another, but she suggests that a descriptive analysis of this phenomenon in translation should be privileged over prescriptive strategies. From a descriptive approach, Van Den Broeck (1981) identifies three translation strategies for the rendering of metaphors:

(i) stricto sensu, or literal translation, by using the same tenor (concept, object, or person being described) and vehicle (the linguistic resources used to describe them) as the source language in the target language. If the vehicles correspond in both languages, the translation will maintain the idiomaticity of the source text; otherwise, it will result in an original metaphor, which may compromise comprehension;

(ii) substitution: the vehicle of the source text is replaced by another in the translated text, maintaining the content, to a greater or lesser extent;

(iii) paraphrase: the metaphor of the source text is paraphrased through a non-metaphorical expression.

Due to the differences between two languages and cultures, we can assume that literal translation will rarely be a suitable alternative for translating metaphors. Substitution is sought as ideal in order to maintain the figurative language in the translated text, while paraphrase can be understood as a necessary evil, as it becomes a viable strategy when the first two are not tangible.

According to Van Den Broeck (1981, p. 77), "[s]ince the task of a theory is not to prescribe, but to describe and to explain, the theory of translation cannot be expected to specify how metaphors should be translated" (emphasis added). Rather, he claims that one should try to describe the phenomena observed with regard to metaphors. We believe that figurative language is a great challenge for translators committed to producing a functional text that flows naturally in the target language, but it is 
essential to maintain the source text idiomaticity. Hence, special attention to figurative language was paid during the construction of the glossary.

Through a study of gastronomical journalism, which investigates reviews and chronicles, Amaral (2006) concludes that Brazilian restaurant reviews use lots of art-related metaphors to refer to food. In his playful Meditation XXVII, Brillat-Savarin (1948) claims that cooking is the oldest of all arts, as Adam must have been born hungry. Also according to the gastronome, cooking is the art responsible for teaching the man how to use fire. As time went by, the status of gastronomy as art may have weakened, as pointed by Capatti and Montanari (1999, p. vII) in the epigraph to this study, but it is still alive in restaurant reviews.

In fact, through the analysis of the keywords we detected a significant number of metaphors and idiomatic expressions in both Brazilian and American reviews, mostly related to arts. To refer to a dish which is outstanding and, as such, frequently ordered by customers, American critics report that it "takes center stage," "is the star of the show," "steals the show," among others. Brazilian reviews also resort to art-related expressions to refer to remarkable orders. But apart from the expressions that refer to acting, such as roubar a cena [steal the scene] and ser a estrela (da casa/do menu) [be the star (of the house/of the menu)], Brazilian critics also resort to the terminology of carnival, a very important Brazilian cultural expression, to refer to a must-order dish, (ser o) carro-chefe [(be the) chief float], the name given to the most important float at the samba school parade. Starters can be referred to as abre-alas [opening wings], the first float of the samba school, following the front commission.

According to Kövecses (2010), sport is also a major source concept that applies to several target domains. The author claims that, as elaborate activities invented to entertain, "games and sport are characterized by certain properties that are commonly used for metaphorical purposes." Restaurant reviews are no exception. An example is the baseball-derived expression "knock it out (of) the (ball)park" to cite a chef who does a wonderful job; acertar o alvo [hit the target], a reference to shooting a target, is the Brazilian critics' preferred choice to address a similar meaning. Sailing is the American critic's choice of metaphor to refer to the person who runs the restaurant or the kitchen ("[X] is at the helm of") whereas the Brazilian writers allude to music and compare the person in charge of the establishment to the conductor of an orchestra (sob a batuta de $X$ [under the baton of $\mathrm{X}]$ ).

As stated by Kövecses (2010), military organizations evoke the overarching metaphor which conveys the idea that complex abstract systems are machines. As a complex machine that has to work properly, a restaurant organization is frequently compared to a military structure. Both American and Brazilian critics refer to the groups of workers who assist the chef at a restaurant as a group of military officers that assist a commander - "staff" and its prima facie equivalent brigada, respectively. "Accoutrement" (usually in the plural form in restaurant reviews), one of the definitions being "[m]ilitary equipment other than uniforms and weapons" ("Accoutrement," n.d.), is used to refer to small-portion accompaniments to the main item, such as coleslaw, dressings, etc. In Brazilian Portuguese reviews, a similar concept is retrieved with acompanhamento or molhinho(s). Guarnição, a term related to a set of troops deployed to a given location, is used by Brazilian critics to refer to the foods that are served along with the main dishes, usually vegetables, rice, and other preparations that can accompany the chosen meat or fish, usually called side dish in English. 
The analysis of the English and Portuguese keywords showed that the genre restaurant review abounds with figurative language, mainly related to arts, sports, and militarism. Nevertheless, the vehicles through which the concept is approached may vary in similar genres written in different languages. In order to maintain conventionality, we suggest that it is rendered with equivalents that are conventional in the Brazilian Portuguese texts, not necessarily with literal, dictionary translations.

\subsubsection{Implicitation vs. Explicitation}

During the analysis of the keywords retrieved from both subcorpora, we noticed that, despite having compiled a comparable corpus of restaurant reviews, following well-defined criteria, and having excluded terms that did not represent the genre as a whole, concepts that are familiar to both languages and cultures were not always present in both lists.

Despite its popularity in the United States, climate-controlled environments are hardly mentioned by the American critics. In the Brazilian Portuguese list, on the other hand, ar-condicionado, ambiente climatizado, and adega climatizada have high keyness, whereas their prima facie equivalents (air-conditioning, air-conditioned room and climate controlled (wine) cellar) are absent from the keyword list in English. We may assume that, rather than understanding the absence of the terms in the English list as the unavailability of the items, they are in fact taken for granted by the critics or, in other words, they remain implicit. Conversely, in the Brazilian dining scene, these elements are explicit in the text for they are considered differentials.

Accessibility is more emphasized in the English subcorpus, in which both wheelchair accessible and accessible restroom are keywords. In the Portuguese subcorpus, we observed only a reference to the first - acesso para deficienteswhereas the adapted restroom seems to be implicit, if at all available.

For the purpose of the glossary, we provide users with a literal equivalent of those entries, followed by a comment to warn them about using those equivalents in the target language, so that translators and writers make a conscious decision while producing texts aimed at the Brazilian audience.

\subsubsection{Culture Bumps}

Newmark (1988, p. 94) defines culture as "the way of life and its manifestations that are peculiar to a community that uses a particular language and its means of expression." As one of the most important cultural expressions of any nation, food gives rise to a number of linguistic elements, many of them representing a unique reality. Culture-specific items are defined by Franco Aixelá (1996) as

[t]hose textually actualized items whose function and connotations in a source text involve a translation problem in their transference to a target text, whenever this problem is a product of the nonexistence of the referred item or of its different intertextual status in the cultural system of the readers of the target text. (p. 58)

To account for the specificities in American and Brazilian restaurant reviews, we borrow Chesterman's(1997, p. 182) term culture bumps, defined as "features that hinder cross-cultural interaction, that prevent smooth communication." The author explains that, if sourceculture-bound features are literally translated, they may hinder comprehension.

Not surprisingly, during this study we raised specific simple and compound keywords used to describe specific American cultural manifestations whose counterparts could not be identified 
in the Brazilian-Portuguese keyword list. After all, as other food-related genres, restaurant reviews are rich in cultural markers (Rebechi \& Tagnin, 2020).

The task of finding equivalents in Portuguese for the English entries revealed two culture bumps: (i) terms that refer to concepts that do not have an equivalent in the target language; and (ii) terms that do have a translation equivalent in the target language, but which could evoke a different image from the one in the source language.

An example of the first bump is the keyword liquor license. Although a literal translation (cf. Chesterman, 1999) -licença para vender bebida alcóolica - could appropriately be used to render the entry in Portuguese, Brazilian readers might wonder why this obvious characteristic of restaurants is highlighted, as in Brazil most food establishments are allowed to serve alcohol without a special permit. In the United States, liquor licenses are regulated differently by each state. They determine, for example, when and where liquor may be served, the amount that can be served, how much it should cost, and to whom it may be served. In addition, there are different licenses for establishments that sell drinks with lower alcohol-by-volume, such as wine and beer, and stronger ones, such as vodka, gin, whisky, etc. To sell all kinds of drinks, establishments must be equipped with a full bar, another keyword that has no equivalent in Brazilian Portuguese, as Brazil does not follow a similar regulation, and allows most restaurants to sell any kind of drinks, for the price and amount decided by the establishments, the only restriction being that people under 18 years are not allowed to have access to alcohol.

Probably due to the differences described above, ВҮОв, the abbreviation for bring your own booze/beer/bottle, is also exclusive to the American reviews. After all, many restaurants allow their customers to bring their own alcoholic drinks, as the owners do not sell them, most likely due to the absence of a liquor license. Brazilian restaurants usually have a single license to sell food and liquor, so the practice of allowing their clientele to take liquor along is not common, except for wine, for which a fee is usually charged. Another example of culture bump whose literal translation would not suit a Brazilian restaurant review is BLT, a classic American sandwich piled with bacon, lettuce, and tomato, ingredients that, alone, would not result in a crowd-pleaser.

The second problem of translation equivalent derives from the fact that a concept may be lexicalized in both languages, but the meaning it evokes is different. For example, the keyword home cooking and its prima facie translation comida caseira. Also among the Portuguese keywords, comida caseira could frustrate Brazilian customers' expectations towards an American restaurant, as they would expect to have ordered their daily beans and rice staple, but would actually receive a steak surrounded by steamed vegetables or mashed potatoes, for example. It goes without saying that there is no single unanimous definition of home cooking even inside one nation. However, we may claim that the term would trigger totally different meanings for Brazilians and Americans. As such, prima facie equivalents alone would not be enough to convey the cultural meaning.

Rebechi and Tagnin (2020) propose a three-level entry - term/equivalent, appositive explanation, and encyclopedic information - to the construction of a Portuguese-English glossary of Brazilian cooking terms aimed at translators and writers of culinary texts. They claim that cultural markers should be addressed in such a way that distinctive cultural characteristics 
of Brazilian cooking are not lost in translation. To that aim, they propose that, instead of adapting items, which may compromise the culture-specific character of the term and hence fail to convey a sense of foreignness, cultural markers be accompanied by a definition, in the form of an appositive explanation which allows translators and writers to include an elucidation of the cultural term without greatly affecting the fluency of the text.

In line with Rebechi and Tagnin (2020), our glossary of terms of restaurant reviews also provides readers with definitions of cultural terms, along with comments when the translation equivalents do not suffice for a comprehensive understanding of the term. Thus, translators and writers are able to decide the best way to explicit these cultural differences in their text.

\section{Discussion}

In the face of what was discussed, it is clear that the translation of restaurant reviews, among other genres in which culturally related elements abound, goes far beyond the search for possible equivalents. The task of producing a text which is at the same time conventional and functional in the target language should take several characteristics into account, from the text length to the types of information which should be privileged or disregarded.

American restaurant reviews are much longer than their Brazilian counterparts, and this difference results mainly from the number of details provided by the former. These details account for the emphasis on the preparation process of the dishes, as well as to the final product, while Brazilian critics privilege the latter. Justifications for overall opinions are also highlighted in the English texts. A careful look at the adverbs ending in -ly, abundant in the English texts, should be considered by the translators, as adverbs ending in -mente may sound excessive in Brazilian Portuguese, a language that shows the recurring characteristic of using diminutive to express precision and affectivity.

Although creativity and variety of synonyms are proper to the genre restaurant review regardless of the language, we noticed that the English terms are much more varied than their Brazilian counterparts. Hence, translators and writers in this area should be presented with the possibilities in order to produce a conventional text either in English or in Portuguese. Technical names of appliances and processes are more common to the American restaurant reviews readers than they are to Brazilians. As such, they seem to be avoided by Brazilian critics.

Abundant in figurative language, mostly related to arts and sports, restaurant reviews show a number of metaphors which are attached to habits observed in each culture. Moreover, the choice of making information implicit or explicit in the text should also take into account the degree to which the element is taken for granted by the target audience. In other words, the translator or writer should have a minimum knowledge of the target culture not to provide it with more or less information than needed. Finally, according to this study, the translator should be informed on how to deal with cultural markers, as a simple transference or literal translation to the target language may hinder the reader's comprehension. Translators and writers are advised to consider those differences when translating from one language to the other, never losing sight of the conventionality expected by the target reader regarding the genre.

Figure 1 shows the entry of the idiomatic expression knock sth. out of the ballpark, used in English reviews to compliment a chef or restaurant for the wonderful job, along with its functional equivalents and examples of use 


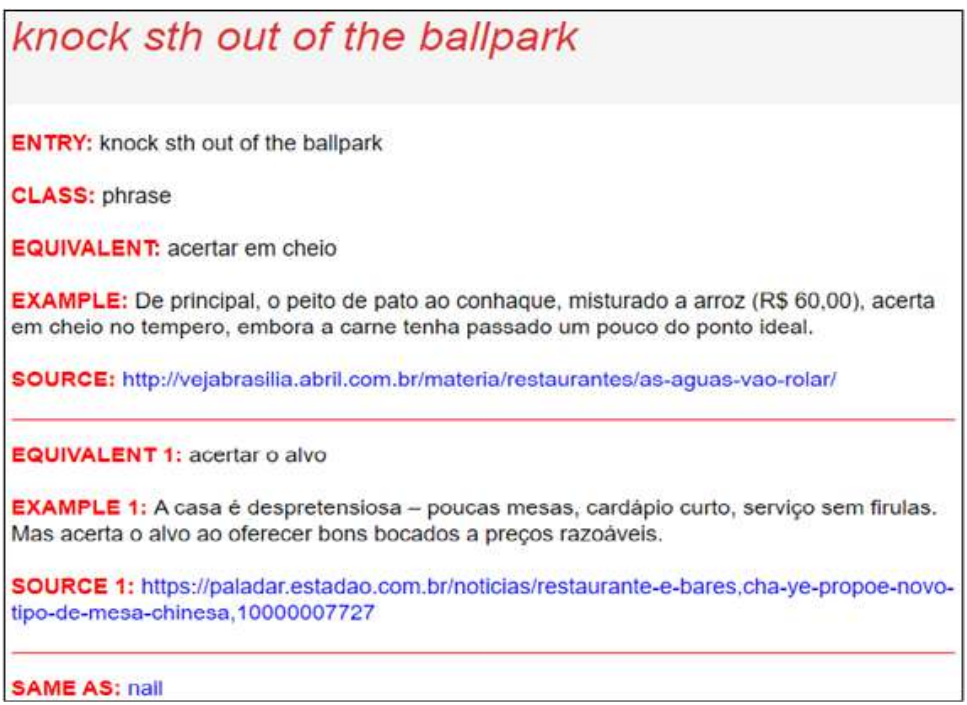

Figure 1. Entry knock sth out of the ballpark in the glossary.

extracted from the Portuguese subcorpus. Through the element same as, the reader is referred to a synonym.

\section{Concluding Remarks}

As a consequence of a long-lasting neglect, food-related reference materials are scarce, and, when available they usually disregard context and cultural differences. General language dictionaries and the few glossaries available on this domain are insufficient to provide translators with proper equivalents of cultural markers, and even when they do, they may fail to inform about source and target language specificities that permeate similar genres. To fill this gap, we proposed the construction of a bilingual glossary containing the terminology of restaurant reviews to help translators and writers produce conventional texts, especially restaurant reviews and menus. To that aim, we applied the methods underlying corpus linguistics to a comparable American English-Brazilian Portuguese corpus of connoisseurial reviews, as they evoke credibility.

A closer look at the keywords demonstrated that not only is this genre filled with culture-specific terms which, naturally, do not have a counterpart in the target language, but it also revealed aspects of a culture that go far beyond words. By analyzing discrepancies between both keyword lists, we attempted to illustrate that rendering a source text term with a prima facie equivalent, even when available, is not always appropriate for the production of a functional translation. The methodology applied to this study made clear that not only were the keywords in both lists paramount for the identification of matches to be used as equivalents, but the mismatch was also essential to reveal differences that should be considered in the translation of the genre.

Although the authors are regular readers of reviews, we discovered a lot about the genre through the bottom-up approach to the corpus which would not be possible through a sequential reading of the texts. By describing the steps taken to reach our objectives, we hope to have shed some light on the task of translating culinary texts from a functional approach.

As a final remark, we recall the epigraph of this article. Perhaps because it is ephemeral, culinary has lost ground to durable arts especially 
as a subject for research. Nevertheless, it should be noted that Capatti and Montanari's (1999) appeal has been heard, as the last two decades granted a number of studies dedicated to this domain.

\section{Acknowledgments}

We are very grateful to Professor Stella Tagnin for her attentive reading and precious suggestions for the improvement of this article.

\section{References}

Accoutrement. (2020). In Merriam-Webster.com. Retrieved Dec 14, 2020, from https://www.merriam-webster.com/dictionary/accoutrement

Aixelá, J. F. (1999). Culture-specific items in translation. In R. Alvarez \& C. M. Vidal (Eds.), Translation, power, subversion (pp. 52-78). Multilingual Matters.

Amaral, R. M.. (2006). Gastronomia: prato do dia do jornalismo cultural [Master's dissertation]. Universidade Federal de Pernambuco, Brazil. https://repositorio.ufpe.br/handle/123456789/3492

Bhatia, V. K. (1993). Analysing genre: Language use in professional settings. Routledge.

Blank, G. (2007). Critics, ratings, and society: The sociology of reviews. Rowman \& Littlefield Publishers.

Brillat-Savarin, J. A. (1948). Physiologie du gout. Charpentier.

Capatti, A., \& Montanari, M. (1999). La cucina italiana. Storia di una cultura. Gius. Laterza.

Chesterman, A. (1997). Memes of translation: The spread of ideas in translation theory. John Benjamins.

Chik, A., \& Vásquez, C. (2017). A comparative multimodal analysis of restaurant reviews from two geographical contexts. Visual Communication, 16(1), 3-26. https://doi. org $/ 10.1177 / 1470357216634005$

Flowerdew, L. (2004). The argument for using English specialized corpora to understand academic and professional language. Studies in Corpus Linguistics, 16, 11-33. https://doi. org/10.1075/scl.16.02flo

Fuchs, S. N. (2018). Orientações culturais e suas implicações para a tradução funcionalista: um estudo na área do turismo à luz da linguística de corpus [Doctoral dissertation]. Universidade de São Paulo, Brazil. https://doi.org/10.11606/T.8.2018. tde-27082018-165601

Le Cordon Bleu Brasil [lecordonbleubrasiloficial]. (2020, August 18). Crítica gastronômica [Instagram video]. https://www.instagram.com/ tv/CEDF4mlHHdG/?igshid=1jepqvelblus8

Jakobson, R. [1959] (2012). On linguistic aspects of translation. In L. Venuti (Ed.), The translation studies reader ( $3^{\text {rd }} \mathrm{Ed}$., pp. 126-132). Routledge.

Johansson, S. (2007). Seeing through multilingual corpora: On the use of corpora in contrastive studies $\left(26^{\text {th }} \mathrm{Ed}\right.$.). John Benjamins.

Katan, D. (1999). Translating cultures: An introduction for translators, interpreters and mediators. St. Jerome.

Kilgarriff, A., Baisa, V., Bušta, J., Jakubíček, M. š., Kováŕ, V. ě., Michelfeit, J., Rychlý, P., \& Suchomel, V. (2014). The Sketch Engine: ten years on. Lexicography, 1(1), 7-36. https://doi. org/10.1007/s40607-014-0009-9

Koester, A. (2010). Building small specialised corpora. In M. McCarthy (Ed.), The Routledge handbook of corpus linguistics (pp. 66-79). Routledge.

Kövecses, Z. (2010). Metaphor: A practical introduction ( $\left.2^{\text {nd }} E d.\right)$. Oxford University Press.

Lakoff, G., \& Johnson, M. (1980). Metaphors we live by. University of Chicago Press.

Li, H., Liu, H., \& Zhang, Z. (2020). Online persuasion of review emotional intensity: A text mining analysis of restaurant reviews. International Journal of Hospitality Management, 89, 1-13. https://doi.org/10.1016/j.ijhm.2020.102558

Lorençato, Arnaldo. (2012) Foreword. In G. Pudlowski, Para que serve um crítico gastronômico? (pp. 7-13). São Paulo: Edições Tapioca.

McEnery, T., \& Hardie, A. (2012). Corpus linguistics: Method, theory and practice. Cambridge University Press.

Marcuschi, L. A. (2003). Gêneros textuais: definição e funcionalidade. In A. P. Dionísio, A. R. 
Machado, \& M. A. Bezerra (Eds.), Gêneros textuais e ensino ( $2^{\text {nd }} \mathrm{Ed}$.). Editora Lucerna.

Moraes, H. F. R. (2015). A questão da equivalência entre os advérbios em -ly e -mente no par de línguas inglês-português: como funciona em linguagens especializadas? In V. Viana \& S. E. O. Tagnin (Eds.), Corpora na tradução (pp. 105-130). HUB.

Motoyama, Y., \& Usher, K. (2020). Restaurant Reviews and Neighborhood Effects. Papers in Applied Geography, 6(4), 386-401. https://doi. org/10.1080/23754931.2020.1791942

Navarro, S. L. M. (2011). Glossário bilíngue de colocações de hotelaria: um modelo à luz da linguistica de corpus (Master's dissertation). Universidade de São Paulo. https://doi.org/10.11606/D.8.2012.tde-16082012-122119

Newmark, P. (1988). A textbook of translation. Prentice Hall.

Nord, C. (2006). Loyalty and fidelity in specialized translation. Confluências: Revista de Tradução Cientifica e Técnica, 29-41.

Nord, C. (2012). Functional approaches to translation. The encyclopedia of applied linguistics (pp. 2223-2228). https://doi. org/10.1002/9781405198431.wbeal0442

Pudlowski, G. (2011). À quoi sert vraiment un critique gastronomique? Armand Colin.

Pudlowski, G. (2012). Para que serve um crítico gastronômico?. Tapioca.

Rebechi, R. R.; \& Moura, M. (2017). Brazilian recipes in Portuguese and English: the role of phraseology for translation. Computational and Corpus-based Phraseology. Cham: Springer, p. 102-114.

Rebechi, R. R.; \& Moura, M. (2018). Obituaries in translation: a corpus-based study. Cadernos de
Tradução, 38(3), 298-318. https://periodicos. ufsc.br/index.php/traducao/article/view/ 2175-7968.2018v38n3p298/37398

Rebechi, R. R.; \& Tagnin, S. E. O. (2020). Brazilian cultural markers in translation: a model for a corpus-based glossary. RiCL-Research in Corpus Linguistics, 8, 65-85. https://ricl.aelinco.es/index.php/ricl/article/view/129

Rebechi, R. R., Schabbach, G. R., \& Freitag, P. H. (2021). Sobre a busca por equivalentes funcionais em um corpus comparável português-inglês de críticas gastronômicas. Tradterm, 37(2), 430-459. https://doi.org/10.11606/ issn.2317-9511.v37p430-459

Sato, E. (2015). Metaphors and translation prisms. Theory and Practice in Language Studies, 5(11), 21832193. https://doi.org/10.17507/tpls.0511.01

Schira, R. (2015). Mangiato bene? As sete regras para reconhecer a boa cozinha. BestSeller.

Stefanowitsch, A. (2020). Corpus linguistics: A guide to the methodology. Language Science Press.

Stewart, D. (2000). Conventionality, creativity and translated text: The implications of electronic corpora in translation. In M. Olohan (Ed.), Intercultural Faultines (pp. 73-91). St. Jerome Pub.

Tagnin, S. E. O. (2013). O jeito que a gente diz. Disal Editora.

Van den Broeck, R. (1981). The limits of translatability exemplified by metaphor translation. Poetics Today, 2(4), 73-87. https://doi. org/10.2307/1772487

Waliszewska, K. (2018). "Alle Revolutionen kommen aus dem Magen" - digital turn und sein Einfluss auf die Textsorte, Restaurantbewertung. Convivium. Germanistisches Jahrbuch Polen, 89-109. https://doi.org/10.18778/21968403.2018.05

How to cite this article: Rebechi, R. R., Nunes, R. R., Munhoz, L. R., \& Marcon, N. O. (2021). Restaurant reviews in Brazil and the USA: A feast of cultural differences and their impact on translation. Mutatis Mutandis, Revista Latinoamericana de Traducción, 14(2), 372-396. https://doi. org/10.17533/udea.mut.v14n2a05 